\title{
Literacy and Language Learning in a Study Abroad Context
}

\author{
R e b e c c a R . K I i n e \\ Pennsylvania State University
}

\section{INTRODUCTION}

"Le Monde is a highbrow paper, but is followed by all serious students." - Nisbet College 1 French Study Abroad Handbook

"Really I think it's better not to read Le Monde at all than read it and not get half of it, because if you mention that you've read something in the paper ... and some French person — like in your family?

- says they read it, too, then you get dragged into a conversation."

— Martha, a participant in Nisbet's French Study Abroad Program

Experiencing someone else's literacy differs radically from learning to read in that person's language. The transition from an American foreign language classroom to a study abroad program site moves students from a reading environment in which most choices — what to read when, where, why, how and with whom - are constrained, to one in which the constraints pale in comparison with the apparent possibilities. It moves them also from a culture in which they are considered literate to one in which they may feel like illiterates. Yet almost no research has been conducted on the reading behaviors and experiences of study abroad participants, and the few investigations that mention reading tend to define it from the classroom or researcher perspective. From that perspective, foreign language reading is a skill to be operationalized in ways that allow it to be measured. It can thereby be studied in its development over time and in its relation to diverse variables (e.g., first language $\{\mathrm{L} 1\}$ reading ability or 
schema familiarity). Learners can, by the same token, be defined in terms of their competence as readers, a process that involves the establishment of normative and criterial standards. Kline (1993) and Kern (1995) have argued against this "traditional” stance toward literacy (Street, 1984) as inimical to current views of the learner and to current instructional practice. In the present article, I aim to (1) comment on the de facto agenda for study abroad research, (2) review briefly the literature on reading and study abroad, (3) argue for a "social practices" view of foreign language literacy, and (4) present findings from an illustrative project in which a qualitative approach framed exploration of study abroad literacy as social practice.

\section{Reading and Study Abroad Research}

\section{An Analysis of Current Practice in Study Abroad Research}

The present issue of Frontiers focuses on the phenomenon of language learning in a study abroad context. In a ground-breaking volume devoted to the same topic, Freed (1995b) assembled chapters reporting on a number of studies that produced, in her words, "an emerging linguistic profile of students who have studied abroad" (iii). The impact of that volume is a vastly expanded understanding of the nature of off-campus study, ranging from awareness of the variety of programs available to recognition that individual variation may actually increase when students are abroad (as compared with their linguistic development at home). In synopsizing her book, Freed alludes to the reigning concerns of study abroad research:

... the studies included in this volume provide some major results which respond to Lambert's suggestion (1990) that we address ourselves to discovering just what is actually learned, by what kind of students, in what type of learning environments, and how this compares with what they would have learned at home (Freed, 1995a, p. 18).

These questions appear to reflect an underlying desire to demonstrate relationships among variables in the language acquisition process and then to compare study abroad results with at-home results. 
Were generalizable answers to such questions available to us, policy makers would be at our doorsteps. We would be in a position to tell them whom to send where, at what point in the language acquisition process, what to do with them once in the culture and how to do it. But the studies in the Freed volume and others (DeKeyser, 1986, 1991; Kline, 1993; Tierney, 1994; Twombly, 1995; Wilkinson, 1995) suggest that the true answer to almost all these questions is "It depends" (see Coleman, 1997, for an overview of some variables). For certain personality types, out-ofclass contexts will be more effective than formal instructional settings (depending, of course, on the nature of each environment). For others, the opposite will be true. In certain target cultures, the arrival of students with no prior knowledge of the language will be acceptable. In others, it will not. Certain study abroad experiences will produce results vastly superior to what could have been achieved stateside, but certain immersion programs will "outperform" many held overseas — depending, of course, on how one defines and measures "results." My point is that the number and instability of variables interacting in a study abroad experience, the complexity of the contexts encountered, and the vast amount that remains unknown about study abroad may impede the quick formulation of answers to nomothetically-oriented questions. We are, in other words, unlikely to find generalizable rules or truths abstracted from the particulars of learner goals, background and personality, or from the particulars of target culture, program profile and language. Even findings of the far ranging ACTR/NFLC studies (e.g., Brecht, Davidson \& Ginsberg, 1993; Brecht \& Robinson, 1993; Ginsberg, 1992; Polanyi, 1995) cannot be extrapolated to other learners, program types or target cultures (as the investigators themselves acknowledge: see Brecht, Davidson \& Ginsberg, 1993, p. 4).

And yet, as noted earlier, one's impression after reading the Freed volume is that one's understanding of study abroad has improved exponentially. How can we account for this discrepancy between what was sought and what was found? If we did not answer the questions, how have we learned so much?

I propose three possible explanations. The first arises from an expanded view of generalizability. Most educators equate generalizability with the claims of probability sampling, as used in research with a "hard science" model. However, "case-to-case translation," as Firestone 
(1993) notes, involves “... transfer of findings from one case study to another ... by the reader ... [in which] the researcher has an obligation to provide a rich, detailed, thick description of the case ... so readers have enough information to assess the match between the situation studied and their own" (p. 18, emphasis added). Perhaps, then, through the Freed volume, readers benefit enough from the rich descriptions of a variety of study abroad experiences to transfer findings to their own situations - in other words, to do the work of generalizing conclusions themselves. If that is the case, it constitutes a powerful argument for expanding the research agenda on study abroad. ${ }^{2}$

A related explanation is that in portraying circumstances and phenomena with a detail not customary in foreign language acquisition research studies, investigators have avoided some of the pitfalls of earlier publications on study abroad which were, in DeKeyser's (1991) words, "entirely speculative" (p. 42). Indeed, much of what had been written on the topic prior to 1990 consisted either of program description (and program director opinion) or of purported program results: non-empirical, retrospective claims for the impact of study abroad.

A third explanation for this enhanced understanding is the inclusion of at least some data reflecting participant perspectives on study abroad. Thus, although Huebner's research aims to compare home country and overseas program proficiency gains (1995, pp. 173-174), his use of diary and interview data opens a window onto the ways students articulate and make meaning of their experiences. Diary comments in other studies (Brecht \& Robinson, 1993; Miller \& Ginsberg, 1993; Polanyi, 1995) allow us to hear students' opinions, their interpretation of events, their emotions and their stories, all expressed in their voice and through their words. These data form a refreshing and compelling contrast to data from "self-report" surveys whose language is not the students' but the researcher's.

With the preceding argument, I do not mean to suggest that we should stop trying to discover the variables responsible for increased linguistic proficiency or the predictors of success in study abroad. I contend, however, that it is equally important, and perhaps even primary, to uncover the larger picture through more open-ended research questions. Likewise, the researcher's frame of reference should not so dominate the field that we neglect to represent learners' beliefs, behaviors and perspec- 
tives or fail to accord them the significance they are due.

Having provided some reflections on the complexity of current work on study abroad generally, I turn to an examination of research on literacy in overseas programs.

\section{Literacy and Reading in the Study Abroad Context}

As Ferguson observes, Americans generally believe that "real fluency" can be achieved only by spending time in a country where the language is spoken (1995, p. xii). Not surprisingly, the goal of many American students in study abroad programs is the achievement of "fluency." This focus on oral expression is paralleled in the profession's concern with communicative competence and proficiency; while both terms refer to more than the ability to produce longer utterances with fewer dysfluencies at a more rapid rate (see Freed, 1995c, for a thorough consideration of qualities encompassed in the term), they nonetheless suggest an emphasis on speaking and face-to-face interaction. The orientation of profession and public alike appears to have influenced the research agenda for study abroad: virtually no studies (other than Kline, 1993) target literacy, reading or writing, and few even mention them. As Ginsberg (1992) observes, "study abroad is not oriented toward reading" (p. 18).

In investigations where reading is considered, it is generally explored as an academic skill, often viewed in terms of its relationship to other variables. In reporting Phase I results of the ACTR/NFLC studies, Brecht, Davidson \& Ginsberg (1993) describe a variety of language measures used to determine characteristics that predict which students would succeed in study abroad programs. Reading test components suggest that reading is being defined in terms of subskills such as the ability to extract factual information from short passages. The view of literacy reflected in these choices thus mirrors that of the home campus foreign language classroom.

In reporting results of their tests, the authors state that pre-program grammar/reading levels emerged as a significant predictor of gains in both listening and oral proficiency (pp. 12, 15, 17), prompting them to suggest that "investment in grammar instruction in the early years of instruction may result in advances in speaking and listening skills at the upper- 
intermediate and advanced levels” (p. 21). Ginsberg (1992), however, posits a need for further research with a focus on "what students actually do during their sojourns abroad" (p. 26).

Indeed, in Phase II of the ACTR/NFLC studies, a qualitative approach to understanding what happens during study abroad was adopted in order to make better sense of the quantitative results obtained during Phase I (Brecht \& Robinson, 1993). Students kept a number of selfreport records such as calendar diaries, while investigators interviewed students, kept fieldwork journals and took fieldnotes on their observations. The calendar diaries, coded on the basis of student entries, make sparse reference to reading: "academic" situations, which represent only about $10 \%$ of the students' time, include the categories of "homework" and "research" (pp. 6-9), both of which can be assumed to involve literacy skills. However, the narrative data presented by the authors in this category are limited to student comments on the role of classes in the language learning process and, specifically, in their impact on spoken language use (pp. 14-16).

With a similar orientation, Freed (1990) discovered that more proficient French students could benefit linguistically from "non-interactive" contact with the language, a category that included reading; less advanced students were better served by interaction with native speakers. Definitive and meaningful conclusions about reading and study abroad are difficult to draw from these studies, since reading is approached largely in terms of a broader effort to understand the linguistic impact of student experiences.

Lapkin, Hart \& Swain (1995) use both self-assessment questionnaires and gains measures in the various language skill areas to determine the "linguistic impact" of a bilingual exchange program in Canada. Their learners were anglophone adolescents, living with francophone host families and attending local schools. The study's test of reading was composed of reading passages accompanied by true/false, multiple choice and openended questions, as well as a section on synonyms (p. 73). The view of reading implicit in this test is, as with the ACTR/NFLC project, textrather than learner-based and product- rather than process-oriented. The self-assessment questionnaire included various categories, within which reading was termed "reading ability" and literacy-related tasks included "read and understand a French newspaper, magazine or popular book," 
"write a letter," and "explain the plot of a mystery book or movie to someone" in a letter (p. 88).

The Study Abroad Evaluation Project, which compared a four-institution group studying at locations in France and Germany to a group remaining in the U.S., likewise used a four-skill, pre- and post-program "self-appraisal scale" to determine students' functional abilities in the L2 (e.g., Can you "say the days of the week," "understand movies without subtitles," etc.). Of the thirty-nine targeted abilities, the greatest increase in student self-assessment was for "read popular novels without using a dictionary" (Carlson et al., 1990, pp. 44-49, 77-79). The salience of this item in the study's results suggests the need for further exploration of, among other topics, its significance to students, its relationship to documented practice (did students in fact read popular novels?), and its implications for the classroom.

Huebner (1995) made use of diaries, interviews and observations to "shed light on the results of the quantitative analyses" (p. 182) of data in his comparison of beginning Japanese students in overseas and home country programs. In Japan, a researcher conducted observations of classes and outside activities, interviewed students and collected their journals. Huebner can report only trends, rather than statistically significant differences in his data, due to the small number of participants in the study. Nonetheless, the widest difference in test scores between the U.S. and the Japan-based groups is in reading (measured by the ETS Japanese Reading Proficiency Test). In explaining the higher performance of the students in Japan, Huebner writes:

... students at the Japan site, finding themselves in an environment in which they were illiterate in the language of the community, had a more urgent need to be literate in Japanese. Frequent reference is made in the journals to the students' frustration with this experience, and virtually all students at the Japan site report attempts to develop their Japanese literacy skills through exposure to the print media, especial$l y$ in public advertising around town and on buses and trains during their daily commutes to and from class ... (p. 185).

All students, continues Huebner, were "disconcerted" by the shift from a context in which they could function as "highly literate" individuals to one in which they could not, despite their differing reactions to 
this experience (p. 186).

Huebner's presentation of student views of literacy broadens and elaborates the research agenda for study abroad, much as do findings on gender in Brecht \& Robinson (1993), Kline (1993), Polanyi (1995) and Twombly (1995). In designing qualitative studies or by including qualitative elements in a research project, these investigators account for context and participant perspective. In the next section, I argue that defining literacy as social practice leads inevitably and appropriately to a qualitative approach to study abroad research, which in turn leads away from a view of reading that is limited to its cognitive aspect.

\section{Exploring the Social Practice of Literacy in $S$ tudy Abroad}

As noted earlier, most current models of reading, whether of L1 or L2, shape and are shaped by a research paradigm and pedagogical agenda that privilege comprehension as a product of reading (typical measurement vehicles - recall protocols, discrete item tests, miscue analyses, etc. - reveal how reading is being defined, both in classrooms and in studies). Researchers examine cognitive processes and teachable skills in an effort to discover variables that may impede or enhance comprehension, leading in turn to the articulation of what Shannon (1989b) terms "context-free theory." Internal validity and reliability have often been emphasized to the detriment of ecological validity (Shannon, 1989a, xv-xvii): as Kamil (1984) explains, in the effort to control extraneous variables, researchers impose unnatural conditions on the subjects of their studies (p. 47). Issues related to reader motivations, values and preferences are rarely considered; likewise, studies often do not account for readers' development over time, their evolving responses to texts, their text-based interaction with others and with the wider environment. Notable exceptions exist, of course (Chiseri-Strater, 1991; Hickman, 1981; Hynds, 1989; Nespor, 1991), but to a far greater degree in L1 than in L2.

Without belaboring the reasons for its dominance, I submit that a psycholinguistic, comprehension- and skills-oriented approach to research on L2 reading (Bernhardt, 1991) interacts synergetically with a quantitative research design. The resulting agenda of research questions has helped to identify a number of factors affecting a student's ability to 
extract information from and make sense of an L2 text, in addition to revealing how reading affects language learning. We know much less, however, about "how the learner sees himself [sic] as a potential reader" (Wallace, 1988, p. 2), or which "purposes for reading and writing ... arise from [the learner's] particular social and cultural needs and expectations" (Kern, 1995, pp. 63-64). We know almost nothing about students as autonomous readers, either in L1 or L2 (see Kline, 1993, pp. 70-73).

The perspectives and types of information missing from our portrait of the L2 reader are hardly impossible to acquire, but uncovering this data appears to involve the adoption of a new set of questions, a new methodological paradigm and new terminology. The choice to call what we are investigating literacy may be the most important step to take.

In traditional views of literacy, labeled by Tuman (1987) as "unproblematic," it is equated with a socioculturally-determined degree of monolithic and non-variable control of reading and writing skills (see Kern, 1995, pp. 62-64). For de Castell and Luke (1983), this view of literacy "a context-neutral, content-free, skill-specific competence" — discourages attentiveness to its "subjective and ... social dimensions" (p. 373).

A group of seminal studies established the inadequacy of this definition and inspired a spate of theorizing beginning in the 1980s. Scribner \& Cole's (1981) research led them to conclude that context of literacy was a critical feature of its acquisition, while Lave et al. (1984) demonstrated that in familiar cultural surroundings, people could perform literate tasks they had failed to accomplish in the classroom. Hynds' (1989) studies of high school literature students demonstrated that they may hide their literacy if revealing it appears to entail risks to identity. And as DelgadoGaitan (1989) contends, people may not "identify their activity as reading because they [do] not perceive themselves as readers" (p. 23). These investigations and others (Heath, 1983; McLaughlin, 1991; Schieffelin \& Gilmore, 1986; Vasquez, 1990) have helped to shape a social practices (Edelsky, 1991) view of literacy. Within this view, literacy is context-and culture-specific (Ferdman, 1990; Gee, 1990), multifarious (Erickson, 1988; Gee, 1990; Scribner \& Cole, 1983), and ideologically bound (Street, 1984). It emerges through processes of acculturation, socialization and apprenticeship (Gee, 1990) and is thus intimately tied to identity.

As students enter the world of second language acquisition, the attainment of literacy would presumably be marked by the ability to cri- 
tique their own native practices and values as socially and culturally constructed, and to leave behind the belief that these practices and values are "natural" or "true" (Barthes, 1968, p. 88). This ability may depend upon traditional skills associated with $\mathrm{L} 2$ reading instruction (the ability to extract information from a text, infer the meanings of unknown words in context, identify main ideas, and so on), but it requires a great deal more. Furthermore, findings of the studies cited above (notably Hynds, 1989, and Delgado-Gaitan, 1989) suggest the academic context is one in which a highly constrained and constraining definition of literacy predominates.

A view of language and literacy acquisition that privileges acculturation and socialization processes (Giles \& Byrne, 1982; Schumann, 1978) encourages us to explore contextual variables and interactional events in researching study abroad experiences. But reading also has an intensely private side. Tuman (1987) posits a distinction between synecdochic language - the deictic language of ordinary conversation - and the language of symbolic representation that characterizes literacy. The latter language is learned in the "struggle ... as we are forced to change in the process of creating or comprehending texts" (p. 24), and it "is used to establish an identity of meaning independent of ... social interaction" ( $p$. 29). Conversation, on the other hand, is usually governed by cooperation in constructing meaning together.

Students overseas, whose primary goal is typically to "become fluent," are likely to favor the development of their conversational language over the development of literacy, if the latter requires a form of separation - transcending the identity one uses in everyday interaction (an identity already "threatened," in some sense, by their marginal status in the new culture [see De Ley, 1975]). Likewise, as the acquisition of literacy prompts students to take a "critical stance toward [their] own experiences" (Tuman, 1987, p. 2), they may well feel beset by multiple allegiances and conflicting desires. Becoming literate in another culture is, in short, a complex undertaking.

The complexity of the phenomenon is a primary rationale for using qualitative methods of inquiry to investigate it, and a number of writers have advocated this approach (Bernhardt, 1991; Guthrie \& Hall, 1988; Heath, 1983; Kline, 1993; Radway, 1984; Smith, 1986; Vasquez, 1990). Duran (1989) enumerates some pertinent advantages: a qualitative approach accommodates complex environments and interactions, attends 
to the relationship of setting and behavior, and inquires into the meaningfulness of artifacts and acts for the actors (pp. 46-47). Although we have seen very few good examples of qualitative studies in journals of interest to foreign language educators, the number appears to be increasing (Amores, 1997; Graden, 1996; Hall \& Davis, 1995; Wilkinson, 1998).

A qualitative approach obeys the rules of inductive logic (Creswell, 1994, p. 7; cf. Morgan \& Smircich, 1980) through a recursive process of data collection and analysis in which categories and concepts emerge over time, rather than being pre-established. Although certain data collection techniques are typically associated with qualitative research, it is not defined by its techniques: indeed, as Morgan \& Smircich point out, "any given technique often lends itself to a variety of uses according to the orientation of the researcher" (1980, p. 498). For them, the appropriateness of a research approach "is contingent on the nature of the phenomena to be studied" (p. 499).

The phenomena to be studied are defined by the questions we seek to answer. If the questions are exploratory and open-ended, if they target the participant's perspective, if they allow for unintrusive investigation of a phenomenon's natural setting, and if they try to account for as many pertinent factors as possible, then a qualitative paradigm is indicated. In general, such questions can be answered only if a fairly lengthy time period is possible for the study and a fairly small number of informants are chosen. Likewise, since the researcher acts as the primary data collection instrument, his or her stance vis-a-vis self and informants must be carefully elaborated.

Research manuals devoted to specific aspects of qualitative investigation abound: study design (Marshall \& Rossman, 1995), data collection and analysis techniques (Bogdan \& Taylor, 1984; Fetterman, 1989; Glaser \& Strauss, 1967; Spradley, 1979, 1980; Wolcott, 1994), evaluative measures (Lincoln \& Guba, 1985, 1986), and reporting format considerations (Van Maanen, 1988; Wolcott, 1990). The reader is referred to these manuals for further information.

Having reviewed the status of reading in research on study abroad, having argued for a "social practices" view of literacy to replace current conceptualizations of $\mathrm{L} 2$ reading, and having defended the logic of the qualitative paradigm for research on student literacy, I now turn to a brief overview of some findings from an investigation of literacy in a college 
study abroad program in France. The elements necessary to presenting this study in ways that establish credibility, dependability, ethical soundness, and transferability (Lincoln \& Guba, 1986) far exceed the page limitations of a journal article; my hope, however, is that the small segment presented here will support the arguments I have made.

\section{Literacy in a Study Abroad Program}

Framed by a social practices model of literacy, the fifteen-month study on which the following comments are based depicts the reading behaviors of eight undergraduate participants in a junior-year abroad program. ${ }^{3}$ Using qualitative techniques, I investigated the nature of literacy in a second language and the impact of moving from the highly constrained reading context of a foreign language classroom to the multifarious environments of family and student life in a large French city.

\section{Study Purposes and Theoretical Framework}

The study had three purposes:

- to account for contextual features of reading, incorporate the emic perspective on literacy, and follow the evolution of reader identity and literate practice over time;

- to respond to calls for empirical and theoretically-framed research on study abroad; and

- to contribute to models of informal learning by exploring the logic and hidden richness of students' "reader lives" (already revealed through a pilot study of L1 college literacy — see Kline, 1990), which their encounter with a non-native culture might bring into sharp focus.

The conceptual framework for the study was articulated around Gee's (1990) notion of Discourses, Tuman's (1987) distinction between literate and synecdochic (or deictic) language, and Giles \& Byrne's (1982) Speech Accommodation Theory (specifically, its view of the role of native identity subgroup membership in supporting language acquisition). 
Informants, Settings, and Program

Of the 22 students in the program, 21 volunteered to participate after hearing an explanation of the study, filling out demographic questionnaires, taking an oral proficiency test, submitting summer reading diaries they had been asked to keep, and participating in an initial interview. The eight informants were chosen through "purposeful sampling" to ensure that major categories for which group diversity provided (gender, social class, academic major, linguistic level, career goals, etc.) were represented.

The student informants were all undergraduates in a small, highly selective liberal arts college (Nisbet) in the northeastern United States. Lack of ethnic and racial diversity is a concern. Fifty per cent of all the college's graduates have participated in a program at one of its study abroad sites, including Marcillac, in southwestern France, reflecting the institution's commitment to international education.

At Nisbet, the students had all taken at least two courses at the post-language requirement level: written expression and introduction to literature. Several had completed two or three additional courses. Oral proficiency interview ratings included intermediate mid or low (twelve students), intermediate high (five students), and advanced (three students). When asked to describe their reading habits, nine believed they read "a lot," five stated they "never read anything," and seven were unsure. Only three had ever done "unassigned reading" in French. They had in common their stated reasons for participating in the Marcillac program: to attain fluency in speech and familiarity with the culture.

In France, students were housed individually with families described by French informants as "la grande bourgeoisie catholique de Marcillac." Two dinners and all breakfasts were provided by the families, and half the students had a "second family" with whom to share one meal per week. Although students usually took one course at a faculté of the French University in Marcillac, the bulk of their program was offered by the Nisbet professor who directed the program or by French faculty hired to give Nisbet courses. Most students had internships in local schools, museums or government agencies.

The Nisbet Study Center in Marcillac housed the classrooms where students took their courses, a library, administrative offices, and a base- 
ment-level area that was exclusively student space: a kitchenette and dining area, "the lounge," and a study area with a bookcase where students abandoned reading materials at the end of their year. The Director's and my apartment was located on the second floor of the building and was the location in which I conducted most interviews.

The year in Marcillac began in September with an intensive period of six weeks, aimed at bringing language skills "up to speed." It included several vacation periods and monthly obligatory weekend excursions to local sites. The year ended with final exams and papers completed from late May to mid June.

\section{Data Collection and Analysis}

The process of data collection and analysis was recursive. Research tools during the ten months in France included ethnographic interviews (over 50), participant observation and artifact inventory (weekly), surveys and questionnaires (once every two months), and document analysis. I visited French family host homes, "trailed" several students during the course of a typical day, and guided eleven volunteers through "miniethnographies" of their French families' reading habits.

Interpretation of data patterns was subjected to triangulation, systematic search for negative case evidence, peer debriefing, member checks, and self-awareness strategies (Lincoln \& Guba, 1986). I sought Geertz' (1973) ideal of "thick description" by layering and embedding voluminous detail in context. My status as a woman and as the Director's wife constituted a potential threat to data validity, so I took steps to ensure the informants' confidentiality and to make my own biases, assumptions and roles — my "situatedness" or subjectivity — clear to them.

\section{Conceptual Categories}

A number of conceptual categories emerged from the data and served to frame the study's conclusions. Data consisted of artifacts (actual print materials ranging from textbooks to food labels to messages left on a blackboard), reading acts, interaction with others, evidence of the impact of literacy or overt reactions. The conceptual categories were literate identity and fellow readers, reading time and space, and reader free- 
doms and constraints. Informants contributed to and/or affirmed the validity of these categories.

\section{Main Findings}

In the voices and portrayals of the eight informants and their experiences is heard a struggle to mediate conflicts: first, the conflict between the avowed academic culture of the program (which students believed and college materials and advising implied - was a replication of the home campus) and the "culture" with which students intended to familiarize themselves while in France; second, the conflict between the portrayal of French culture promulgated by Nisbet (which characterized the French as possessed of great "culture générale" and obsessed with knowledge of current events) and the reality students discovered in their families (where everyone subscribed to Télé 7 Jours and only a few read Le Monde); finally, the conflict between their sense of identity as American students and the identity they perceived as "apprentices" to French literate culture.

Faced with these conflicts, program participants created a hybrid subculture that sustained them in their evolution through the year. Its literacies, elaborated in the categories described above, represent a new Discourse (Gee, 1990) and thus an opportunity to critique constructively both practices they encountered in France and practices that had been transplanted from the Nisbet home campus to Marcillac via course and program requirements.

In an effort to convey the character of the struggles and their mediation, I include here several scenarios representative of the types of phenomena that helped me to categorize, articulate, and understand my findings. In the first, some student encounters with French and programsponsored literacies are presented.

\section{(1)Whose Literacy Is It?}

Students had been encouraged to seek out interaction with their families and were specifically advised to read Le Monde and the canonical literary works of their academic courses by Nisbet faculty and study abroad personnel. Their first encounters with families allowed them to 
test the validity of this advice. One woman reported:

I was downstairs reading Les Rois maudits and my French father said, "Ob!" like be didn't think I could read anything that hard. He picked up the book and turned to the first page, and even though I was on about page 30, he read the whole first page out loud to me. And be explained what everything meant, like I didn't know. I was like, "You know, I can read this," but be just kept on and on ... it was just like, "Americans can't read this — it's too hard!"

In addition to challenging the students' ability to read French, host family members objected to the inappropriateness of certain texts: "If they see me reading something," explained a student, "they often say, 'Oh, we read that 20 years ago, but we hated it." A French father stated, "We French wouldn't go to see Britannicus at the theater, so why are they taking you to see it?" Students began to wonder what they could or should read, given the contradiction between what their program and the families were advising. Eric and Martha tried the local paper, La Dépêche $d u$ Midi, but Eric's family criticized the paper as "poorly written," and Martha reported, "They had a heart attack when they heard I was reading it, but I like it — it helps me know what's going on in Marcillac." In comparing these two texts, we see that the French were rejecting two polar staples of student reading diets, both abroad and on the home campus: a local newspaper and required coursework. The paper was disdained because of poor writing, and in spite of its relevance to Marcillac newcomers. Britannicus was vetoed as inappropriate despite its exquisite use of language. Signals from the French were thus mixed, and students found it difficult to cast them in the role of "masters" of a Discourse to which they were apprenticed. Lynn, termed the most serious student in the group by the others, offered an opinion: "Reading is not a priority to give to a foreigner, like food is."

Certain texts did tend to foster interaction between the students and their hosts. The film version of L'Amant, which the students were reading for a Nisbet course, premiered in Marcillac during the winter, as did a "renarration" by Duras. Students were aware that controversy surrounded both the film and the novels, due to the "shocking sex scenes," but it became a favorite of many. Their Nisbet professor reflected on its popularity: 
Well, they had the movie, for one thing: the sex, the exotic setting, the love story. And mainly, actually, the messed-up family situation... you know, we have a lot of kids this year who come from broken families, and they had a lot to say ... I wanted them to think about the nature of autobiography, who the narrator was, and so on - but they really wanted to psychoanalyze the girl.

Professor Franklin went on to speculate about the role L'Amant began to play in discussions between family and students: "Duras is someone the families need to be able to talk about now. So the students could be on a sort of equal footing with the French in a conversation, because love and sex and family problems are part of their lives, so they really know about it." Indeed, Eric — a self-described "poor reader" — pointed out that he had begun a conversation with his French mother by mentioning a fact about the novel that she did not know.

L'Amant linked students to their families for three reasons: families were likely to be aware of it (so the topic of conversation was easily opened), students identified with themes and characters through personal experience and/or the knowledge gained in the classroom, and students felt confidence in speaking because they had read the book and seen the movie. These sorts of conditions were rarely all met, however, and students found text-based interaction rather daunting when any were absent.

Many in the group weighed the risks of appearing literate or of engaging in literate behaviors with the French. One woman wanted to read something in French for pleasure but refused to ask her French family for a recommendation since, "They might ask if I liked it and I might have to say I didn't understand." Students found that "pointing to an article in the paper and saying 'Je ne comprends pas' " prompted French interlocutors to take the lead in text-based conversation, however the damage to their egos of "playing dumb" was, over time, considerable. As Martha noted, "a newspaper like Le Monde is saying to you, 'This is here for people who already understand.' " Furthermore, as Tuman (1987) observes, they had to assess the cost of jeopardizing the development of their interactional identities by becoming more literate. Beth pointed out that she could not even eat lunch and read Le Monde simultaneously, since she "lost the thread just by taking a bite of [her] sandwich!"; this constraint threatened her ability to accomplish the "reader goals" of exchanging opinions 
with friends in an informed way and reading during a meal. The International Herald Tribune presented no such obstacles.

Students were thus stymied in their encounters with French and academic literacies in Marcillac. The next section reports findings related to their reactions and responses to these encounters.

\section{(2) Literate Identity in a Student Subculture}

One reaction to the sometimes alienating encounters with French literacies was the establishment of hybrid practices within the students' own community in France. The following scene is illustrative:

In the Nisbet Center student lounge, a tinny rendition of "Mustang Sally" whispered from the boom box. Stretched the length of the sofa, left arm propped behind his head, Tom read a paperback copy of Le Colonel Chabert. His Birkenstocked foot kept the beat silently from its roost on the sofa armrest. Deirdre appeared from the kitchen area and let her backpack drop to the floor. The small plastic tub of ersatz onion dip, concocted weekly by the students from dried soup and crème fraîche, caught ber eye. "On mange ici," she accused, and drew a chair to the coffee table, pushing aside the coverless and well-thumbed Let's Go France. Reaching for the bag of potato chips, she asked, "You finish the reading?"

This scene includes both familiar and novel responses to the challenge of becoming literate in a foreign language. Tom was reading French in new ways, handling an authentic French text without a dictionary or note-taking in a context full of potential distraction. And, although he and Deirdre were in France, the environment was woven from American college campus elements: music, food, postures, clothing and attitudes towards coursework. A number of literacy-related phenomena characterized this hybrid context.

Small, text-based "reading clubs" developed in the group. The three men continued their American habit of reading and sharing the sports pages of English-language newspapers. And the group's four vegetarians read food labels systematically to provide each other with information about nutrition during a year that challenged their refusal to eat meat as their families struggled to understand what vegetarianism was ("I put 
bacon in the spinach to give it a little flavor," explained Lynn's French mother, "but I took it out before I served it to you, so it's not really meat"). These clubs allowed for maintenance and development of identity in ways that supported students as they explored new forms of reading among the French (see Giles \& Byrne, 1982).

The student subculture was gender-differentiated. Women tended to read more and to experiment with a greater variety of texts, borrowing more from the library than did the men and seeking out "the French version of Cosmo" or "a book in French like the one I read on the plane coming over." Women used the communal blackboard to write messages in French, a practice sneered at by the men. And women positioned themselves in ways that invited shared reading, while men did not (for example, the men tended to lie on the student lounge sofa when reading the newspaper, thus leaving no room for a fellow reader to sit down). In general, the men's behavior suggested an effort to conserve and maintain habits; the women displayed more pliant attitudes and willingness to change.

\section{(3) Evolution}

Students in the Marcillac program were given the chance to "change in the process of creating and comprehending texts" (Tuman, 1987, p. 24): a few acknowledged, after months of complaining about the inappropriateness of academic coursework (cf., Brecht \& Robinson, 1995; Miller \& Ginsberg, 1995), that they appreciated having learned to "look for the deeper meaning" in books, films and other texts and being able to read more independently. Likewise, men and women abandoned some gender-specific behaviors by the end of the year. Finally, interaction with the French improved for some, as family members began to recommend books or to discuss course-related readings with the students over dinner.

\section{Discussion and Conclusions}

My hunch in designing this study was that exposure to unfamiliar literacies during study abroad would lead students to apprentice themselves to new, uniquely French Discourses. As stated earlier, I intended to document this process over time and to contribute to our understanding of study abroad by exploring contextual features of reading and the emic 
perspective. As the findings summarized briefly above indicate, the students took an unexpected path. Their choices reveal the potential of the study abroad context to increase our knowledge of student literacy in both L1 and L2.

By regarding L2 students as literates, rather than as readers, I replaced a focus on skills with a focus on identity and context. The view problematized "deficiency models" of student behavior and enriched the portrait of the L2 reader in the target culture. My observations challenge the claim that most students do not like to read, indicating instead that they prefer some texts and some ways of reading to others, and that these preferences may be based on reasonable assessment of the costs and benefits of displaying one's literate identity.

\section{Implications for Theory and Practice}

The "ethnographic intent" of the study precludes formulation of specific recommendations for practice. Nonetheless, arguments in favor of certain institutional and investigative stances derive logically from its findings and are consonant with an effort to facilitate case-to-case transfer as a form of reader-based generalization. The following postures could attune faculty and program directors to literacy overseas and thereby enable an increase in understanding, as well as the development of appropriate policies and routines:

- a willingness to make clear the nature of the academic reading to which a college subscribes, its "constructedness" and contingency (even on a college campus), and its status in the study abroad contexts where students will find themselves;

- the curiosity necessary to uncover student reading habits and literacy events in the target culture, and the willingness to supply them with tools to read host texts critically;

- a sensitivity to the "costs" of L2 literacy, rather than a preoccupation with its purported benefits; and

- a readiness to rethink the "master narrative" of study abroad, embodied in myths about the culture, about language acquisition (e.g., the ubiquitous "no English" rule), and about the impact of the experience.

Future research might extend the findings of the present study in a 
number of directions. Clearly, similar investigative approaches to literacy in other countries or among students with different purposes would enhance the understanding gained through exploration of the Marcillac group's experiences. In view of gender differences uncovered in the present study, the role of such factors as ethnicity, race, sexual orientation or social class would be worth exploring. In addition, as a corpus of data evolves and expands, we should be attentive to links between pedagogical practice, programmatic policy and out-of-class learning. Finally, more longitudinal and qualitative studies of overseas groups should be undertaken to augment the knowledge gained from retrospective, experimental or outcomes-oriented research.

Given the urgency of learning to interact effectively and appropriately with native speakers, student participants in study abroad programs may not appear to read or to respond to the literate practices they observe, much less to use texts as a basis for conversation. In allowing us to attend to myriad features of a phenomenon and in uncovering hidden student behaviors, beliefs and attitudes, a qualitative approach improves our understanding of the meanings, complexities and costs of forging new literate identities overseas. This knowledge is a foundation for exploring what happens in related domains (cognitive, pedagogical, linguistic) and a rationale for including literacy in the larger effort to understand the phenomenon of study abroad.

\section{Notes}

1 A pseudonym, as are all names of places, institutions and individuals.

2 It is worth noting that fewer than five articles on study abroad appeared in The Modern Language Journal and Foreign Language Annals during the period 1992-1997.

3 Space limitations preclude a detailed presentation of study design, data, arguments, findings, and conclusions. The reader is referred to Kline (1993) for a full description of the study. 


\section{REFERENCES}

Amores, M. J. 1997. A new perspective on peer editing. Foreign Language Annals 30 (4): 513-522.

Barthes, R. 1968. L'effet de réel. Communications 11.

Bernhardt, E. B. 1991. Developments in second language literacy research: Retrospective and prospective views for the classroom. Foreign language acquisition research and the classroom ed. B.F. Freed, 221-251. Heath Series on Foreign Language Acquisition Research and Instruction. Lexington, MA: D. C. Heath.

Bogdan, R., \& S. J. Taylor. 1984. Introduction to qualitative research methods: The search for meanings. 2nd ed. New York: John Wiley \& Sons.

Brecht, R. D., D. Davidson, \& R. Ginsberg. 1993. Predictors of foreign language gain during study abroad. NFLC Occasional Paper. Washington, DC: National Foreign Language Center

Brecht, R. D., \& J. Robinson. 1993. Qualitative analysis of second language acquisition in study abroad: The ACTR/NFLC Project. NFLC Occasional Paper. Washington, DC: National Foreign Language Center.

Brecht, R. D., \& J. Robinson. 1995. On the value of formal instruction in study abroad: student reactions in context. Second Language Acquisition in a Study Abroad Context ed. B.F. Freed, 317-334. Amsterdam and Philadelphia: John Benjamins.

Carlson, J. S., B. B. Burn, J. Useem, \& D. Yachimowicz. 1990. Study abroad: The experience of American undergraduates. Westport, CT: Greenwood Press.

Chiseri-Strater, E. 1991. Academic literacies: The public and private discourse of university students. Portsmouth, NH: Boynton/Cook Publishers.

Coleman, James A. 1997. Residence abroad within language study. Language Teaching 30: 1-20.

Creswell, J. W. 1994. Research design: Qualitative and quantitative approaches. Thousand Oaks, CA: Sage.

De Castell, S., \& A. Luke. 1983. Defining "literacy" in North American schools: Social and historical conditions and consequences. Journal of Curriculum Studies 15: 373-389.

DeKeyser, R. M. 1986. From learning to acquisition. Foreign language development in a US classroom and during a semester abroad. Unpublished Ph.D. dissertation, Stanford University. 
DeKeyser, R. M. 1991. Foreign language development during a semester abroad. Foreign language acquisition research and the classroom ed. B. F. Freed, 104-119. Heath Series on Foreign Language Acquisition Research and Instruction. Lexington, MA: D. C. Heath.

De Ley, H. 1975. Organized programs of study in France: Some contributions of stranger theory. French Review 48: 836-847.

Delgado-Gaitan, C. 1989. Mexican adult literacy: New directions for immigrants. Becoming literate in English as a second language eds. S. R. Goldman and H. T. Trueba, 9-32. Cognition and Literacy. Norwood, NJ: Ablex Publishing.

Duran, R. 1989. Factors affecting development of second language literacy. Becoming literate in English as a second language eds. S. R. Goldman and H. T. Trueba, 33-55. Cognition and Literacy. Norwood, NJ: Ablex Publishing.

Edelsky, C. 1991. With literacy and justice for all. Critical Perspectives on Literacy and Education. London: The Falmer Press.

Erickson, F. 1988. School literacy, reasoning, and civility: An anthropologist's perspective. Perspectives on literacy ed. E. R. Kintgen, B. M. Kroll, and M. Rose, 205-226. Carbondale: Southern Illinois University Press.

Ferdman, B. M. 1990. Literacy and cultural identity. Harvard Educational Review 60: 181-204.

Ferguson, C. 1995. Foreword. Second Language Acquisition in a Study Abroad Context ed. B. F. Freed, xi-xv. Amsterdam and Philadelphia: John Benjamins.

Fetterman, D. 1989. Ethnography: Step by step. Newbury Park, CA: Sage. Firestone, W. A. 1993. Alternative arguments for generalizing from data as applied to qualitative research. Educational Researcher 22 (4): 16-23.

Freed, B. F. 1995a. Language learning and study abroad. Second Language Acquisition in a Study Abroad Context ed. B. F. Freed, 3-33. Amsterdam and Philadelphia: John Benjamins.

Freed, B. F. 1990. Language learning in a study abroad context: The effects of interactive and non-interactive out-of-class contact on grammatical achievement and oral proficiency. Linguistics, language teaching and language acquisition: The interdependence of theory, practice and research ed. J. Alatis. Georgetown Round Table on Linguistics. Washington DC: Georgetown University Press. 
Freed, B. F. (ed). 1995b. Second Language Acquisition in a Study Abroad Context. Studies in Bilingualism. Amsterdam and Philadelphia: John Benjamins.

Freed, B. F. 1995c. What makes us think that students who study abroad become fluent? Second Language Acquisition in a Study Abroad Context ed. B. F. Freed, 123-148. Amsterdam and Philadelphia: John Benjamins.

Gee, J. P. 1990. Social linguistics and literacies: Ideology in discourses. Critical Perspectives on Literacy and Education. London: The Falmer Press.

Geertz, C. 1973. The interpretation of cultures: Selected essays. New York: Basic Books.

Giles, H., \& J. L. Byrne. 1982. An intergroup approach to second language acquisition. Journal of Multilingual and Multicultural Development 3: 17-40.

Ginsberg, R. 1992. Language gains during study abroad: An analysis of the ACTR data. National Foreign Language Center Working Papers. Washington, DC: National Foreign Language Center.

Glaser, B. G., \& A. L. Strauss. 1967. The discovery of grounded theory: Strategies for qualitative research. New York: Aldine.

Graden, E. C. 1996. How language teachers' beliefs about reading instruction are mediated by their beliefs about students. Foreign Language Annals 29 (3): 387-395.

Guthrie, L. F., \& W. S. Hall. 1988. Ethnographic approaches to reading research. Handbook of reading research ed. P. D. Pearson, 91-110. New York: Longman.

Hall, J. K., \& J. Davis. 1995. What we know about relationships that develop between cooperating and student teachers. Foreign Language Annals 28 (1): 32-48.

Heath, S. B. 1983. Ways with words: Language, life, and work in communities and classrooms. Cambridge: Cambridge University Press.

Hickman, J. 1981. A new perspective on response to literature: Research in an elementary school setting. Research in the Teaching of English 15 (4): 343-354.

Huebner, T. 1995. The effects of overseas language programs: Report on a case study of an intensive Japanese course. Second Language Acquisition in a Study Abroad Context ed. B. F. Freed, 171-193. Amsterdam and Philadelphia: John Benjamins. 
Hynds, S. 1989. Bringing life to literature and literature to life: Social constructs and contexts of four adolescent readers. Research in the Teaching of English 23: 30-61.

Kamil, M. L. 1984. Current traditions of reading research. Handbook of reading research ed. P. D. Pearson, 39-62. New York: Longman.

Kern, R. 1995. Redefining the boundaries of foreign language literacy. Redefining the boundaries of language study ed. Claire Kramsch, 61-98. Issues in Language Program Direction. Boston: Heinle \& Heinle, Publishers.

Kline, R. R. 1993. The social practice of literacy in a program of study abroad. Unpublished Ph.D. dissertation. The Pennsylvania State University.

Kline, R. R. 1991. Subversive reading: The text in the real world and the text of the real world. Paper presented at the twelfth annual Ethnography in Education Forum, Philadelphia.

Lave, J. et al. 1984. The dialectic of arithmetic in grocery shopping. Everyday cognition: Its development in social context ed. B. Rogoff and J. Lave, 67-94. Cambridge: Harvard University Press.

Lapkin, S., D. Hart, \& M. Swain. 1995. A Canadian interprovincial exchange: Evaluating the linguistic impact of a three-month stay in Quebec. Second Language Acquisition in a Study Abroad Context ed. B. F. Freed, 67-94. Amsterdam and Philadelphia: John Benjamins.

Lincoln, Y. S., \& E. G. Guba. 1985. But is it rigorous? Trustworthiness and authenticity in naturalistic evaluation. Naturalistic evaluation ed. by D. D. Williams, 78-84. San Francisco: Jossey-Bass.

Lincoln, Y. S., \& E. G. Guba. 1986. Naturalistic inquiry. Beverly Hills, CA: Sage.

Marshall, C., \& G. B. Rossman. 1995. Designing qualitative research. 2nd ed. Thousand Oaks, CA: Sage.

McLaughlin, D. 1991. When literacy empowers: An ethnography of uses for English and Navajo print. Albuquerque, NM: University of New Mexico Press.

Miller, L., \& R. B. Ginsberg. 1995. Folklinguistic theories of language learning. Second Language Acquisition in a Study Abroad Context ed. B. F. Freed, 293-315. Amsterdam and Philadelphia: John Benjamins.

Morgan, G., \& L. Smircich. 1980. The case for qualitative research. Academy of Management Review 5 (4): 491-500.

Nespor, J. 1991. The construction of school knowledge: A case study. 
Rewriting literacy: Culture and the discourse of the other eds. C. Mitchell and K. Weiler, 169-188. Critical Studies in Education and Culture Series. New York: Bergin and Garvey.

Polanyi, L. 1995. Language learning and living abroad: Stories from the field. Second Language Acquisition in a Study Abroad Context ed. B.F. Freed, 271-291. Amsterdam and Philadelphia: John Benjamins.

Radway, J. 1984. Reading the romance: Women, patriarchy, and popular literature. Chapel Hill: The University of North Carolina Press.

Schieffelin, B. B., \& P. Gilmore (eds). 1986. The acquisition of literacy: Ethnographic perspectives. Advances in Discourse Processes 21. Norwood, NJ: Ablex Publishing.

Schumann, J. 1978. The acculturation model for second language acquisition. Second language acquisition and foreign language teaching ed. R. Gingras, Arlington, VA: Center for Applied Linguistics.

Scribner, S., \& M. Cole. 1981. The psychology of literacy. Cambridge: Harvard University Press.

Shannon, P. 1989a. Broken promises: Reading instruction in twentieth century America. Granby, MA: Bergin and Garvey.

Shannon, P. 1989b. Paradigmatic diversity within the reading research community. Journal of Reading Behavior 21: 97-107.

Smith, D. M. 1986. The anthropology of literacy acquisition. The acquisition of literacy: Ethnographic perspectives eds. B. B. Schieffelin and P. Gilmore, 261-275. Advances in Discourse Processes 21. Norwood, NJ: Ablex Publishing.

Spradley, J. P. 1979. The ethnographic interview. New York: Holt, Rinehart \& Winston.

Spradley, J. P. 1980. Participant observation. New York: Holt, Rinehart \& Winston.

Street, B. 1984. Literacy in theory and practice. Cambridge: Cambridge University Press.

Tierney, W. G. 1994. Knowledge and difference: A critical analysis of study abroad. Paper presented at the annual meeting of the American Educational Research Association, New Orleans.

Tuman, M. C. 1987. A preface to literacy: An inquiry into pedagogy, practice, and progress. Tuscaloosa: The University of Alabama Press.

Twombly, S. B. 1995. Piropos and friendships: Gender and culture clash in study abroad. Frontiers: The Interdisciplinary Journal of Study Abroad 
1: 1-27.

Van Maanen, J. 1988. Tales of the field: On writing ethnography. Chicago: University of Chicago Press.

Vasquez, O. A. 1990. Connecting oral language strategies to literacy: An ethnographic study among four Mexican immigrant families. Unpublished Ph.D. dissertation. Stanford University.

Wallace, C. 1988. Learning to read in a multicultural society: The social context of second language literacy. Language Teaching Methodology Series. New York: Prentice Hall.

Wilkinson, S. 1995. Foreign language conversation and the study abroad transition: A case study. Unpublished Ph.D. dissertation. The Pennsylvania State University.

Wilkinson, S. 1998. Study abroad from the participants' perspective: A challenge to common beliefs. Foreign Language Annals 31 (1): 23-39.

Wolcott, H. F. 1994. Transforming qualitative data: Description, analysis, and interpretation. Thousand Oaks, CA: Sage.

Wolcott, H. F. 1990. Writing up qualitative research. Newbury Park, CA: Sage. 